\title{
HYPOPONERA RAGUSAI (EMERY, 1895) A CAVERNICOLOUS ANT NEW FOR THE IBERIAN PENINSULA (HYMENOPTERA, FORMICIDAE)
}

\author{
A. Tinaut
}

\begin{abstract}
In this study, we cite Hypoponera ragusai for the first time in the Iberian Peninsula, this species being distributed throughout the North Africa, southern Italy and southern France.

This species shows cavernicolous behaviour in Sicily. In Spain the only three localities known until the moment are also cavities, one in the province of Almería (Sima Termal), other in the province of Málaga (Cueva de Nerja) and the other in the province of Granada (Cueva del Barranco Iñate). The population studied in the Cueva del Barranco Iñate presents, throughout the year, three castes typical of formicids - that is, workers, females and males - in addition to eggs and larvae. The constant presence of brood, aptery in the females and males, as well as their limitation to the cavernicolous environment raise the possibility that this might even be a species, or at least populations, that are strictly cavedwelling, considerations discussed in depth in this paper.
\end{abstract}

Key words: Hypoponera ragusai, biospeleology, new cite, Formicidae, Hymenoptera.

\section{RESUMEN}

\section{Hypoponera ragusai (Emery, 1895) una hormiga cavernícola nueva para la península Ibérica (Hymenoptera, Formicidae)}

En este artículo se cita por primera vez para la península Ibérica a Hypoponera ragu$s a i$, especie distribuida por el norte de África, sur de Italia y sur de Francia.

Esta especie se comporta como cavernícola en Sicilia. Las tres únicas localidades conocidas hasta el momento para Andalucía son también cavidades, una en la provincia de Almería (Sima Termal), otra en la provincia de Málaga (Cueva de Nerja) y la otra de la provincia de Granada (Cueva del Barranco Iñate). La población estudiada en la Cueva del Barranco Iñate presenta a lo largo de todo el año las tres castas típicas de los formícidos, es decir, obreras, hembras y machos, además de huevos y larvas. La presencia constante de prole, el apterismo de las hembras y de los machos, así como su limitación al medio cavernícola nos hace plantearnos la posibilidad de que se trate efectivamente de una especie, o al menos de unas poblaciones, estrictamente troglobias, lo que se discute en este artículo.

Palabras clave: Hypoponera ragusai, bioespeleología, nueva cita, formícidos, himenópteros.

\section{Introduction}

Hypoponera ragusai was described for Sicily (Emery, 1895) and later was cited for Algeria, Tuni- sia, Syria, central Sahara, eastern Africa and certain localities of France (see Mei, 1992), but as this author indicates, it is doubtful that all these records refer to the same species.

* This work form part of the project Fauna Iberica II (DGICYT PB89-0081).

** Departamento de Biología Animal y Ecología. Universidad de Granada, 18071 Granada. Spain. e-mail: hormiga@goliat.ugr.es 
In Sicily, this ant is invariably found in cavities, and therefore can be considered, at least in that area, to be a cavedweller (Baroni Urbani 1962; Mei 1992). Outside Sicily, its distribution does not appear to be restricted to caves, although it is considered more endogeous than others of the genus (Bernard, 1968).

This species, until now not recorded for the Iberian Peninsula, has been found in the Cueva del Barranco de Iñate, near the village of Lobres (Granada), in the Sima Termal (Sierra de Gádor, El Ejido, Almería) and in Cueva de Nerja (Málaga). The record of this species in the Iberian Peninsula for the first time, as well as a discussion of its cavedwelling character constitute the objectives of the present paper.

\section{Material studied}

The material was identified fundamentally on the basis of the drawing and work of Mei (1992). In addition, this author corroborated that the Andalusian and Sicilian specimens were the same species. The diagnostic features to identify this species involve the profile of the petiole, almost cylindrical, subpetiolar process clearly convex (fig. 1), mandibles with irregular teeths (fig. 2) and the tegument polished and with frequents upright hairs.

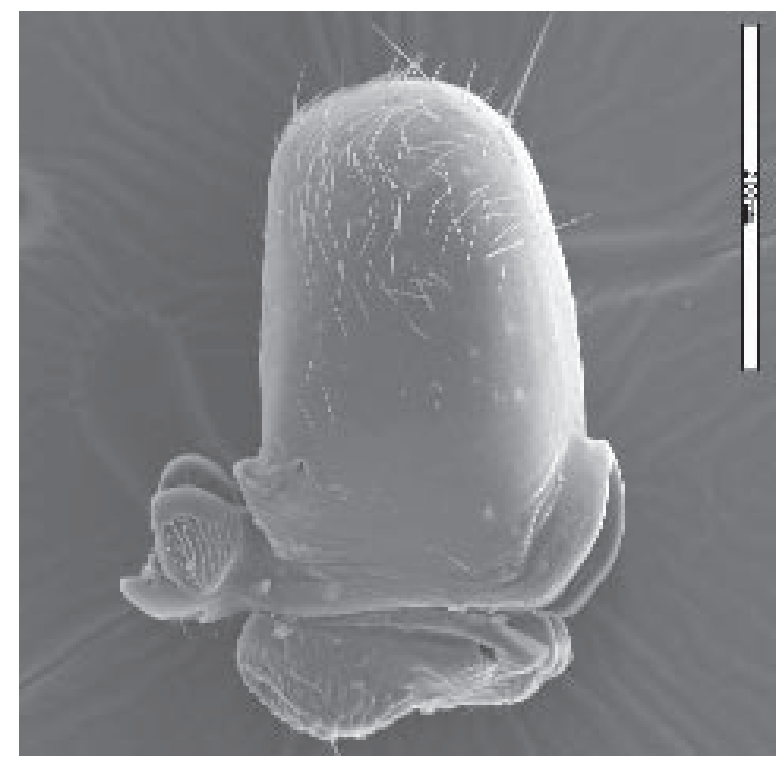

Fig. 1.- Petiole of the worker of H. ragusai.

Fig. 1.- Peciolo de la obrera de H. ragusai.
This work is focused mainly on the population found in the Cueva del Barranco Iñate, a cave known also as Cueva del Capitán and Cueva de los Sudores, and it appears in the official province list of caves, noted as SB-6. This cave is some 200 metres deep and has a rather numerous colony of bats which provide an abundant mass of bat guano. The temperature of this cave in the inner zones is some $23.5^{\circ} \mathrm{C}$ and $100 \%$ relative humidity. The majority of the arthropod fauna of this cave are comprised of troglophile species, although there are some troglobite species, which are under study.

This ant, as indicated above, was found in the Sima Termal, situated in the Sierra de Gádor and which also has noteworthy troglobite fauna. In this case, only two specimens were collected in pitfall traps, with no additional references for the abundance of this species.

In the Cueva del Barranco Iñate, this ant is found frequently some $20 \mathrm{~m}$ away from the entrance of the cave, in the troglobious environment, both in the cave walls and the floor, and especially in the guano deposits. The ants are irregularly distributed throughout the cave floor, under rocks and under the guano itself, and the precise limits of the ant nests could not be clearly discerned. It is very likely that the nests have no fixed location, being constituted by a network of galleries and chambers scattered horizontally on the cave floor. In successive visits during different periods of the year, over a

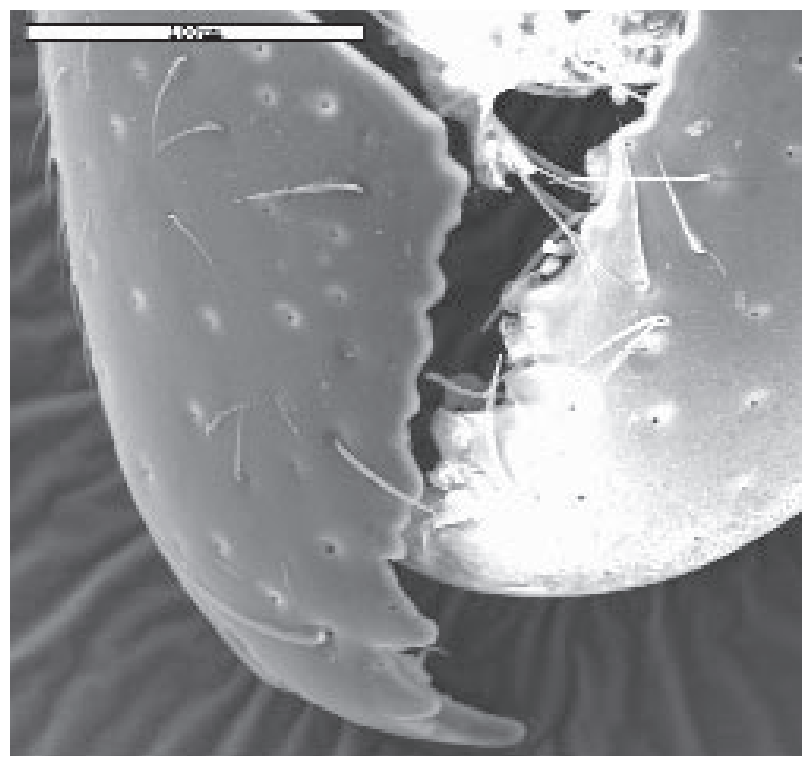

Fig. 2.- Mandibles of the worker of H. ragusai.

Fig. 2.- Mandíbulas de la obrera de H. ragusai. 


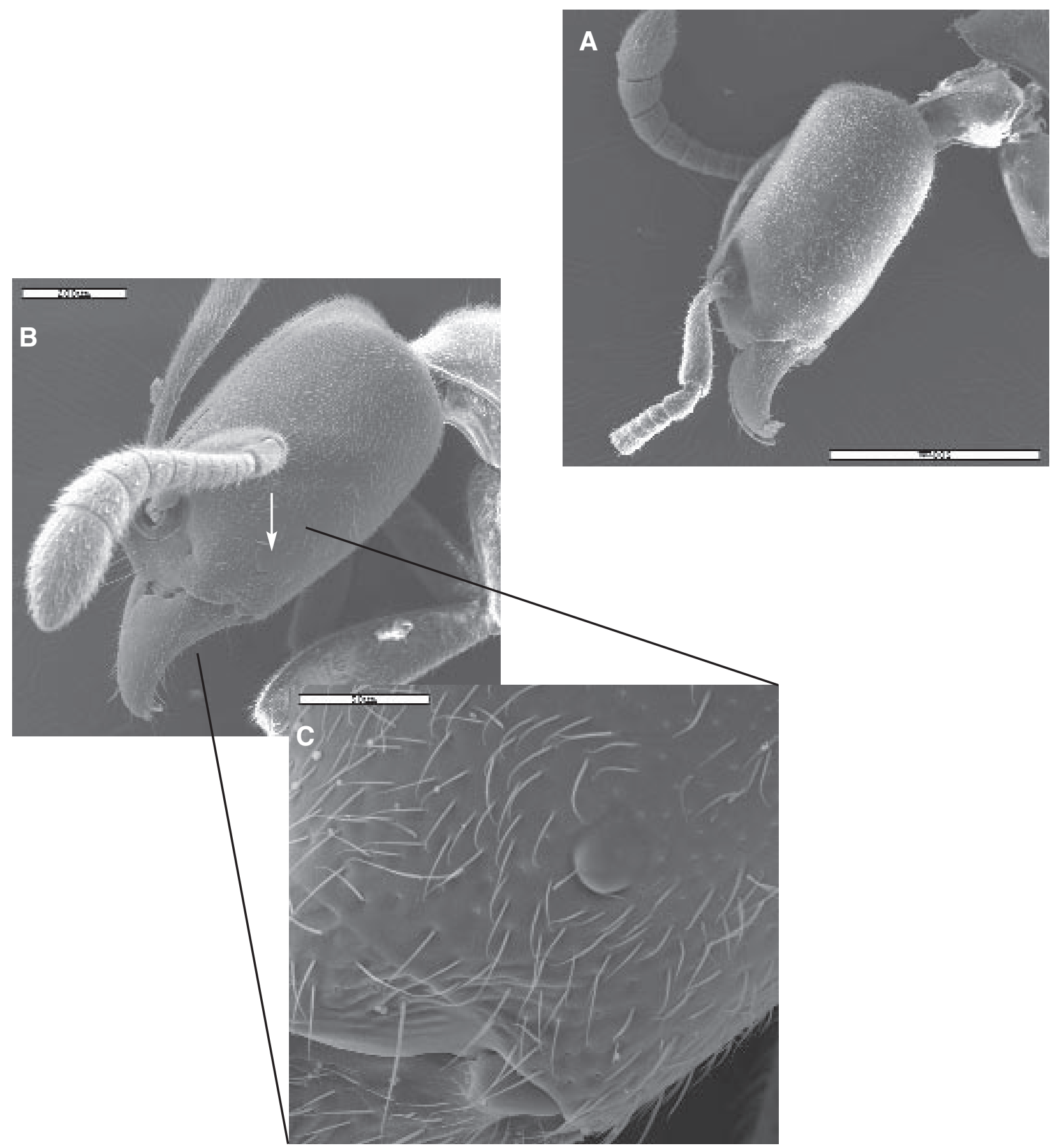

Fig. 3.- A: Head in profile of the male of H. ragusai. B: Head in profile of the worker of H. ragusai. C: detail of the worker's head. Note the absence of eyes in the males and the small eyes in the worker.

Fig. 3.- Perfil de la cabeza del macho (A) y de la obrera (B) de H. ragusai. C: detalle de la cabeza de la obrera. Nótese la ausencia de ojos en los machos y su pequeño tamaño en la obrera. 
period of two years, we found workers and queens, as well as a constant presence of larvae and males, although these were invariably low in number. Two nests or populations collected on 16 October 1998 were comprised, respectively, of: 1 male, 6 females, 14 workers, 3 larvae, 37 eggs; and 1 male, 4 females, 6 workers, 10 larvae and 35 eggs.

In no case did we find isolated females, although these have been described by Santschi (1907) from specimens collected in Kairouam (Algeria), nor did we find winged males. Santschi (1908) also described a winged male from Kairouam, but with doubts regarding the species. Until then, the only males described (Santschi, 1907) were all ergatoid. Our males match the description of Santschi (1907) reasonably well, with the only exception that 3 of the 5 males studied were completely blind (fig. 3A), a characteristic not reported until now. The workers showed very small eyes (figs. 3B and C).

\section{Discussion}

Despite that ants have frequently been found in the caves, up to now no species has been clearly considered troglobite in the strict sense (Decu et al., 1998). There are major objections, both empirical and theoretical, against considering ants truly troglobite (Tinaut and López, 2001). One of the main objections is that most ants found in caves actually come from sites where there were no strict cavernicolous conditions, such as partially illuminated zones and cave entrances or exterior areas surrounding caves. Most authors in fact consider these findings to be accidental and assign a trogloxenic status to the species found (Jeannel, 1926; Conci, 1951; Vandel, 1964; Ginés, 1982, Martín et al., 1985; Izquierdo et al., 1986). Another objection is that there are only two records of ant nests found inside caves: a colony of Oligomyrmex urichi (Wheeler, 1922) found in Trinidad (Wilson, 1962) and another one of Lasius umbratus (Nylander, 1846) found in Spain (López, 1988). Although more significant than the records of individuals, these do not constitute proof, either, of the association of these ant species with cavernicolous environment.

Assuming that the discovery of a nest in a cave constitutes much stronger evidence of non-accidental presence of ants inside it, the number of records of a species in cavernicolous and noncavernicolous environments should be contrasted in order to ascertain its cavernicolous status. Both
O. urichi and L. umbratus have been found nesting in caves only once, whereas they have been recorded from many other kinds of outside environments (Emery, 1875; Wheeler, 1910; Stärcke, 1937; Wilson, 1962; Collingwood, 1963, 1979). Thus, despite their proven cave-nesting capability, these ants could hardly be considered troglophilic. Furthermore, as Wilson himself pointed out (Wilson, 1962), ants found in caves typically belong to species which are abundant and widespread in habitats outside caves. Therefore, the presence of ants in caves has been regarded as highly accidental in most cases.

In the case of H. ragusai, Mei (1992) pointed out that the relationship between this species and the caves in the region of Sicily "is due to the scarcity of favourable environments for a hygrophilous and lucifugous ant".

The caves where we found $H$. ragusai in the Iberian Peninsula were surrounded by very arid environments, with rainfall of 300 to 400 litres per year. Therefore, we could consider caves in these environments to be the only resources of constant moisture. However, in the Iberian Peninsula, other nine species belonging to the subfamily Ponerinae are known, all of which have underground habits. Some of these species, namely $H$. punctatissima (Roger, 1859) and P. coarctata (Latreille, 1802), are found in caves in the Iberian Peninsula (Ginés, 1982; Espadaler, 1983), but in no case have nests been found in the interior of the caves, and also their records are reduced to a few cases. On the contrary, these species are relatively widespread in the exterior environment, although invariably linked to the moisture. For example, $H$. eduardi (Forel, 1894) is found in winter or spring in the surroundings of the Cueva del Barranco Iñate (Ortiz and Tinaut, 1989).

Therefore, the search for a moist, constant microclimate in the caves, particularly when moisture begins to be scarce on the exterior, may constitute a major initial cause for the colonization of caves by many arthropods (Bellés, 1987). Therefore could also be the initial cause in the case of Ponerinae species, favoured by the hypogeal character of all the palearctic species, as well as the presence of polymorphic males, some normally winged and others wingless in some of their species (Hölldobler \& Wilson, 1990). Nevertheless, it appears that this is not the case with $H$. ragusai, but rather that this species or at least the populations described are adapted exclusively to cave life, being capable of reproducing in the interior of the caves. In addition, both males and 
females have lost their wings and reduced or lost their eyes, a phenomenon common among troglomorphs arthropods (Bellés, 1987; Culver et al., 1995), and which may be considered therefore as an ecomorphological characteristic common to these environments.

A characteristics shared by most cave organisms is a highly restricted geographic range with no closely related surface-dwelling relatives (Culver et al., 1995). Therefore one major problem that this situation poses is the wide distribution of $H$. ragusai as well as the non-cavernicolous character of the populations outside Sicily and the Iberian Peninsula. Although insects can have different cavernicolous habits depending on latitude (Bellés, 1987), it is striking that the same species appears in such different karstic systems so distant from one another (south Spain and Sicilia). This distribution is difficult to explain because it would imply the extinction of the non-cavernicolous european populations and an absence of speciation for the cavernicolous populations, inhabitual in systems as closed as those of caves (Culver et al., 1995).

\section{ACKNOWLEDGEMENTS}

We thank Maurizio Mei for help in the identification of the specimens from Andalusia. Francisco López provided useful ideas concerning social insects and caves. Paqui Ruano suffered my visits to the caves. Dolores Martínez for the revision of the manuscript. Different speleologists have helped collecting material: Manuel González Ríos, Marta Fernández-Reinoso and Mariola Lara. Pablo Barranco, G. Pardo y M. Piquer collected and sent me material from Almería. To David Nesbit for the English translation. This work has been partially supported by the Patronato de la Cueva de Nerja and is included in the Project $n^{\circ} 448$ of the UNESCO: "World-wide correlation of kasrtic ecosystems".

\section{References}

BARONi Urbani, C., 1962. Studi sulla mirmecofauna d'Italia. I. Redia, 47: 129-138.

BELlÉs, X., 1987. Fauna cavernicola i intersticial de la península Ibérica i les illes Balears. CSIC y Moll. Mallorca. 207 pp.

BERnARD, F., 1968. Les fourmis (Hym. Formicidae) d'Europe occidentale et septentrionale. Masson. Paris. 411 pp.

Collingwood, C. A., 1963. The Lasius (Chtonolasius) umbratus (Hym. Formicidae) species complex in North Europe. The Entomologist, 96: 145-158.
Collingwood, C. A., 1979. The Formicidae (Hymenoptera) of Fennoscandia and Denmark. Fauna Entomologica Scandinavica, 8: 1-174.

Conci, C., 1951. Contributo alla conoscenza delle spelleofauna della Venezia Tridentina. Memorie della Societa Entomologica Italiana, 30: 5-76.

Culver, D. C., Kane, T. C. \& Fong, D. W., 1995. Adaptation and natural selection in caves. Harvard University Press. Cambridge. 223 pp.

Decu, V., Casale, A., Scaramozzino, P. L., López, F. \& Tinaut, A., 1998. Hymenoptera. In: C. Juberthie \& V. Decu (Eds.). Encyclopaedia Biospeologica. Sociétè de Biospéologie. Moulis: 1015-1024.

EMERY, C., 1875. Le formiche ipogée con descrizioni di specie nuove o poco note. Annali del Museo Civico di Storia Naturale di Genova, 7: 465-474.

ESPADAlER, X., 1983. Sobre formigues trobades en coves (Hym. Formicidae). Speleon, 26/27: 53-56.

GINÉs, A., 1982. Inventario de especies cavernícolas de las Islas Baleares. Endins, 9: 57-75.

Hölldobler, B. \& Wilson, E. O. 1990. The Ants. The Belknap Press of Harvard University Press. Cambridge. $732 \mathrm{pp}$.

IzQuierdo, I., MedinA, A. L. \& DíAZ, M., 1986. La fauna invertebrada en las cuevas La Labrada y Las Mechas (Tenerife, Islas Canarias). Vieraea, 16: 309-320.

JeAnnel, R., 1926. Faune cavernicole de la France. Le Chevalier. Paris. 334 pp.

LÓPEZ, F., 1988. Descripción de un nido de Lasius umbratus (Nylander, 1864) encontrado en el interior de una cueva y algunas consideraciones sobre el carácter cavernícola de las hormigas (Hym., Formicidae). Mémoires Biospéologiques, 15: 107-115.

Martín, J. L., Oromí, P. \& Barquín, J., 1985. Estudio ecológico del ecosistema cavernícola de una sima de origen volcánico: La Sima Robada (Tenerife, Islas Canarias). Endins, 10/11: 37-46.

MeI, M., 1992. Su alcune specie endogee o criptobiotiche della mirmecofauna italiana. (Hymenoptera, Formicidae). Fragmenta Entomologica, 23: 411422.

Ortiz, F. J. \& Tinaut, A., 1989. Formícidos del litoral granadino. Orsis, 3: 145-163.

SAntschi, F., 1907. Fourmis de Tunisie. Capturées en 1906. Revue Suisse de Zoologie, 15: 305-334.

SANTSCHI, F., 1908. Nouvelles fourmis de l'Afrique du nord (Egypte, Canaries, Tunisie). Annales de la Société Entomologique de France, 77: 517-534.

STÄrCKE, A., 1937. Retouches sur quelques fourmis d'Europe. II. Lasius groupe umbratus Nylander. Tijdschrift Entomologische, 80: 38-72.

TinAuT, A., 1998. Artrópodos terrestres de las cavidades andaluzas. Zoologica Baetica, 9: 3-28.

Tinaut, A. \& LóPez, F., 2001. Ants and caves: sociabi- 
lity and ecological constraints (Hymenoptera, Formicidae). Sociobiology, 38: 1-9.

VANDEl, A., 1964. Biospéologie. La biologie des animaux cavernicoles. Gauthier-Villars. Paris. 619 pp.

WheELER, W.M., 1910. Ants: their structure, development and behaviour. Columbia University Press. New York. 663 pp.
WiLson, E. O., 1962. The Trinidad cave ant Erebomyrma (= Spelaeomyrmex) urichi (Wheeler), with a comment on cavernicolous ants in general. Psyche, 69: 63-72.

\author{
Recibido, el 16-XI-2000 \\ Aceptado, el 16-III-2001 \\ Publicado, el 00-XX-2001
}

